\title{
Two Novel er1 Alleles Conferring Powdery Mildew (Erysiphe pisi) Resistance Identified in a Worldwide Collection of Pea (Pisum sativum L.) Germplasms
}

\author{
Suli Sun ${ }^{1}$, Dong Deng ${ }^{1}$, Canxing Duan ${ }^{1}{ }^{\mathbb{D}}$, Xuxiao Zong ${ }^{1}$, Dongxu $\mathrm{Xu}^{2}{ }^{2}$, Yuhua He ${ }^{3}$ and \\ Zhendong Zhu ${ }^{1, *}$ \\ 1 National Key Facility for Crop Gene Resources and Genetic Improvement, Institute of Crop Sciences, \\ Chinese Academy of Agricultural Sciences, Beijing 100081, China; sulisun@caas.cn (S.S.); \\ q2499363366@163.com (D.D.); duancanxing@caas.cn (C.D.); zongxuxiao@caas.cn (X.Z.) \\ 2 Zhangjiakou Academy of Agricultural Sciences, Zhangjiakou 075000, China; xudongxu1972@163.com \\ 3 Yunnan Academy of Agricultural Sciences, Kunming 650205, China; erbio@163.com \\ * Correspondence: zhuzhendong@caas.cn; Tel.: +86-10-82109609; Fax: +86-10-82109608
}

Received: 22 August 2019; Accepted: 30 September 2019; Published: 12 October 2019

\begin{abstract}
Powdery mildew caused by Erysiphe pisi DC. severely affects pea crops worldwide. The use of resistant cultivars containing the er1 gene is the most effective way to control this disease. The objectives of this study were to reveal er 1 alleles contained in 55 E. pisi-resistant pea germplasms and to develop the functional markers of novel alleles. Sequences of 10 homologous PsMLO1 cDNA clones from each germplasm accession were used to determine their er1 alleles. The frame shift mutations and various alternative splicing patterns were observed during transcription of the er1 gene. Two novel er1 alleles, er1-8 and er1-9, were discovered in the germplasm accessions G0004839 and G0004400, respectively, and four known er 1 alleles were identified in 53 other accessions. One mutation in G0004839 was characterized by a 3-bp (GTG) deletion of the wild-type PsMLO1 cDNA, resulting in a missing valine at position 447 of the PsMLO1 protein sequence. Another mutation in G0004400 was caused by a 1-bp (T) deletion of the wild-type PsMLO1 cDNA sequence, resulting in a serine to leucine change of the PsMLO1 protein sequence. The er1-8 and er1-9 alleles were verified using resistance inheritance analysis and genetic mapping with respectively derived $F_{2}$ and $F_{2: 3}$ populations. Finally, co-dominant functional markers specific to er1-8 and er1-9 were developed and validated in populations and pea germplasms. These results improve our understanding of E. pisi resistance in pea germplasms worldwide and provide powerful tools for marker-assisted selection in pea breeding.
\end{abstract}

Keywords: Erysiphe pisi; er1-8; er1-9; KASPar marker; pea

\section{Introduction}

Pea (Pisum sativum L.) is a widely distributed legume crop, which frequently suffers from various stresses, including abiotic and biotic factors in the season of growth [1,2]. Powdery mildew, induced by Erysiphe pisi DC., severely reduces the yield and quality of pea crops worldwide [3-5]. Severe E. pisi infections of peas can lead to yield losses of up to $80 \%$ in regions which are suitable for disease development $[5,6]$. The use of resistant cultivars carrying the E. pisi-resistant gene er 1 has been considered to be the most effective and environmentally friendly way to prevent this disease to date $[6,7]$.

Formerly, E. pisi infection was the only known cause of pea powdery mildew. However, since 2005, two other Erysiphe species, Erysiphe trifolii and Erysiphe baeumleri, have been reported to also infect peas and induce the same powdery mildew symptoms as E. pisi in some regions [8-10]. Previous 
studies of pea powdery mildew have primarily focused on breeding peas resistant to E. pisi. Their results have indicated that resistance to E. pisi is controlled by two single recessive genes (er1 and er2) and one dominant gene (Er3) [11-14]. The er1, er2, and Er3 genes have been mapped using linked markers [15-27]. The genes er 1 and er 2 map to pea linkage groups (LGs) VI and III, respectively [17,28]. Er3, which was isolated from wild pea (Pisum fulvum), was initially mapped on an uncertain pea LG, but it was more recently assigned to pea LG IV [29].

As er1 confers high resistance or complete immunity to E. pisi in most pea germplasms, it is currently the most widely used gene in pea production [30]. In contrast, er 2 is only found in a few pea germplasms resistant to E. pisi [30]. Moreover, the efficacy of E. pisi resistance conferred by er2 varies with leaf development stage and plant location [12,30-32]. Er3 was known from wild pea (P. fulvum), and there have not been extensive studies conducted to date [13,33].

Gene er 1 confers stable, durable, and broadly effective resistance to E. pisi. This gene inhibits the incursion of E. pisi into pea epidermal cells [32]. Recent studies have shown that the er1-resistant phenotype is caused by loss-of-function mutations in the pea MLO (Mildew Resistance Locus O) homolog (PsMLO1). The MLO gene family has been identified in both dicots (e.g., Arabidopsis thaliana and tomato: Solanum lycopersicum) and monocots (e.g., barley: Hordeum vulgare) [14,34-39].

To date, nine er1 alleles resistant to E. pisi have been identified in E. pisi-resistant pea germplasms: er1-1 (also known as er1mut1) [14,21,25,40,41], er1-2 [14,24,25], er1-3 [14], er1-4 [14], er1-5 [38], er1-6 [27], er1-7 [26], er1-10 (also known as er1mut2) [21,40,42], and er1-11 [42,43]. Each er1 allele corresponds to a different $P_{S} M L O 1$ mutation site and pattern. Among the nine er1 alleles identified, only er1-1 and er1-2 are commonly applied in pea breeding programs [14,38]. Several studies have attempted to design functional markers of er 1 alleles to allow for the rapid selection of pea germplasms resistant to E. pisi $[24,26,27,38,42-44]$.

The yield and quality of the Chinese pea crop are severely damaged by powdery mildew [2], with the disease affecting up to $100 \%$ of pea plants in some regions of China [4]. Several studies have focused on the identification of Chinese pea germplasms resistant to E. pisi [41,44-49]. In the Chinese pea cultivars X9002 and Xucai 1, E. pisi resistance is conferred by the er1-2 allele [24,25,47], while in some Chinese pea landraces from Yunnan Province, E. pisi resistance is conferred by the er1-6 allele [27,48]. E. pisi resistance in the Indian pea cultivar DDR11 is conferred by the er1-7 allele [26]. Thus, natural resistance to E. pisi conferred by the er 1 gene has been observed in pea germplasms worldwide, providing a rich source of genetic material that can be used to improve the E. pisi resistance of Chinese pea cultivars $[41,46,48,50]$. Allelic diversity of this locus in the cultivated pea has been well characterized; however, relatively few studies have investigated and characterized E. pisi-resistant pea germplasms in an international collection. Thus, this study aimed to identify and characterize the $E$. pisi-resistant alleles at the er1 locus in a worldwide collection of pea germplasms resistant to E. pisi. Additionally, any novel er1 alleles were genetically mapped, and functional markers specific to these novel er1 alleles were developed to improve marker-assisted selection in pea breeding programs.

\section{Results}

\subsection{Phenotypic Evaluation}

Fifty-five E. pisi-immune or -resistant pea germplasm accessions from 13 countries were re-evaluated for their resistance to the E. pisi isolate EPYN. At 10 days post-inoculation, the E. pisi disease severity of all susceptible controls (Bawan 6 and Longwan 1) were rated as score 4 . In contrast, the 55 E. pisi-resistant germplasm accessions appeared to be either immune (symptom-free; disease severity 0) or resistant (slight infection; disease severity 1-2) to E. pisi isolate EPYN. Of the 55 resistant germplasm accessions, 46 were classified as immune and nine as resistant to E. pisi (Table 1). To provide comprehensive information for the resistance of a worldwide collection of 86 pea germplasms to E. pisi, the phenotypes of 31 resistant pea germplasms carrying known er 1 alleles are also shown in Table 1. 
Table 1. Information about phenotype and the resistance gene at the er1 locus of the 86 Erysiphe pisi-resistant and the two E. pisi-susceptible controls (two controls are bolded).

\begin{tabular}{|c|c|c|c|c|c|}
\hline No. & Accession No./Germplasm Name & Origin & Phenotype & er1 Allele & Reference \\
\hline 1 & G0004389 & Afghanistan & I & er1-8 & This study \\
\hline 2 & G0004382 & Australia & I & er1-1 & This study \\
\hline 3 & G0004400 & Australia & I & er1-9 & This study \\
\hline 4 & G0004417 & Australia & I & er1-2 & This study \\
\hline 5 & G0004434 & Australia & I & er1-2 & This study \\
\hline 6 & G0004448 & Australia & I & er1-2 & This study \\
\hline 7 & G0004450 & Australia & I & er1-2 & This study \\
\hline 8 & G0002102 & Canada & I & er1-6 & This study \\
\hline 9 & G0006514 & Canada & $\mathrm{R}$ & er1-2 & This study \\
\hline 10 & G0006515 & Canada & $\mathrm{R}$ & er1-2 & This study \\
\hline 11 & G0006516 & Canada & I & er1-2 & This study \\
\hline 12 & G0006519 & Canada & I & er1-2 & This study \\
\hline 13 & G0003925 & Canada & I & er1-1 & [41] \\
\hline 14 & Cooper & Canada & I & er1-1 & [41] \\
\hline 15 & G0005576 & China, Chongqing & I & er1-2 & [27] \\
\hline 16 & G0006273 & China, Gansu & I & er1-2 & [24] \\
\hline 17 & 20012 & China, Gansu & I & er1-1 & This study \\
\hline 18 & $\mathrm{Jia} 2$ & China, Gansu & I & er1-2 & This study \\
\hline 19 & Texuan11 & China, Gansu & I & er1-2 & This study \\
\hline 20 & Hehuan66 & China, Gansu & $\mathrm{R}$ & er1-1 & This study \\
\hline 21 & Longwan 1 & China, Gansu & $\mathrm{S}$ & $E r 1$ & [51] \\
\hline 22 & PI391630 & China, Guangdong & I & er1-4 & [14] \\
\hline 23 & Xucai1 & China, Hebei & I & er1-2 & [25] \\
\hline 24 & G0003694 & China, Hebei & $\mathrm{R}$ & er1-6 & [27] \\
\hline 25 & Bawan 6 & China, Hebei & $\mathrm{S}$ & $E r 1$ & [24] \\
\hline 26 & L0314 & China, Yunnan & I & er1-1 & [51] \\
\hline 27 & L1332 & China, Yunnan & I & er1-2 & [51] \\
\hline 28 & L1335 & China, Yunnan & I & er1-2 & [51] \\
\hline 29 & G0001747 & China, Yunnan & $\mathrm{R}$ & er1-6 & This study \\
\hline 30 & G0001752 & China, Yunnan & I & er1-6 & [27] \\
\hline 31 & G0001763 & China, Yunnan & I & er1-6 & [27] \\
\hline 32 & G0001764 & China, Yunnan & I & er1-6 & [27] \\
\hline 33 & G0001767 & China, Yunnan & I & er1-6 & [27] \\
\hline 34 & G0001768 & China, Yunnan & I & er1-6 & [27] \\
\hline 35 & G0001773 & China, Yunnan & I & er1-6 & This study \\
\hline 36 & G0001777 & China, Yunnan & I & er1-6 & [27] \\
\hline 37 & G0001778 & China, Yunnan & I & er1-6 & [27] \\
\hline 38 & G0001780 & China, Yunnan & I & er1-6 & [27] \\
\hline 39 & G0003824 & China, Yunnan & $\mathrm{R}$ & er1-6 & [27] \\
\hline 40 & G0003825 & China, Yunnan & I & er1-6 & [27] \\
\hline 41 & G0003826 & China, Yunnan & I & er1-6 & [27] \\
\hline 42 & G0003831 & China, Yunnan & $\mathrm{R}$ & er1-6 & [27] \\
\hline 43 & G0003834 & China, Yunnan & $\mathrm{R}$ & er1-6 & [27] \\
\hline 44 & G0003836 & China, Yunnan & $\mathrm{R}$ & er1-6 & [27] \\
\hline 45 & G0003839 & China, Yunnan & $\mathrm{R}$ & er1-6 & This study \\
\hline 46 & G0005117 & China, Yunnan & I & er1-6 & This study \\
\hline 47 & G0003974 & China, Yunnan & I & er1-7 & This study \\
\hline 48 & G0003975 & China, Yunnan & I & er1-7 & This study \\
\hline 49 & Yunwan4 & China, Yunnan & $\mathrm{R}$ & er1-1 & This study \\
\hline 50 & Yunwan18 & China, Yunnan & $\mathrm{R}$ & er1-2 & This study \\
\hline 51 & Yunwan35 & China, Yunnan & I & er1-2 & This study \\
\hline 52 & Yunwan37 & China, Yunnan & I & er1-6 & This study \\
\hline 53 & L2157 & China, Yunnan & I & er1-2 & This study \\
\hline 54 & G0002848 & Denmark & I & er1-2 & This study \\
\hline 55 & G0002971 & England & I & er1-2 & This study \\
\hline 56 & G0002859 & Germany & I & er1-2 & This study \\
\hline 57 & G0002860 & Germany & I & er1-2 & This study \\
\hline 58 & G0002883 & Germany & I & er1-2 & This study \\
\hline 59 & G0003895 & ICRISAT & I & er1-7 & [26] \\
\hline 60 & G0003897 & ICRISAT & I & er1-2 & This study \\
\hline 61 & G0003899 & ICRISAT & I & er1-7 & [26] \\
\hline 62 & G0003907 & ICRISAT & I & er1-2 & This study \\
\hline 63 & G0003911 & ICRISAT & I & er1-2 & This study \\
\hline 64 & G0003961 & India & I & er1-2 & This study \\
\hline 65 & G0003967 & India & I & er1-7 & [26] \\
\hline 66 & G0003958 & India & I & er1-7 & [26] \\
\hline 67 & G0006285 & Japan & $\mathrm{R}$ & er1-2 & This study \\
\hline 68 & G0004332 & Mexico & $\mathrm{R}$ & er1-1 & This study \\
\hline 69 & G0004394 & Nepal & $\mathrm{R}$ & er1-7 & [26] \\
\hline 70 & G0002980 & Unknown country & I & er1-2 & This study \\
\hline
\end{tabular}


Table 1. Cont.

\begin{tabular}{|c|c|c|c|c|c|}
\hline No. & Accession No./Germplasm Name & Origin & Phenotype & er1 Allele & Reference \\
\hline 71 & G0003931 & Unknown country & I & er1-7 & [26] \\
\hline 72 & G0003935 & Unknown country & I & er1-2 & This study \\
\hline 73 & G0003936 & Unknown country & I & er1-7 & [26] \\
\hline 74 & G0003942 & Unknown country & I & er1-1 & This study \\
\hline 75 & G0003943 & Unknown country & I & er1-1 & This study \\
\hline 76 & G0002128 & USA & I & er1-2 & This study \\
\hline 77 & G0002129 & USA & I & er1-2 & This study \\
\hline 78 & G0002131 & USA & I & er1-2 & This study \\
\hline 79 & G0002132 & USA & I & er1-2 & This study \\
\hline 80 & G0002134 & USA & I & er1-2 & This study \\
\hline 81 & G0002137 & USA & I & er1-2 & This study \\
\hline 82 & G0002183 & USA & I & er1-2 & This study \\
\hline 83 & G0002235 & USA & I & er1-6 & This study \\
\hline 84 & G0002250 & USA & I & er1-2 & This study \\
\hline 85 & G0002602 & USA & I & er1-2 & This study \\
\hline 86 & G0002608 & USA & I & er1-2 & This study \\
\hline 87 & G0002847 & USA & I & er1-2 & This study \\
\hline 88 & G0002960 & USA & I & er1-2 & This study \\
\hline
\end{tabular}

\subsection{PsMLO1 Sequence Analysis}

The PsMLO1 cDNA sequence of Bawan 6 and Longwan 1, the susceptible controls, was consistent with that of the wild-type PSMLO1 cDNA (Table 1). Among the 55 resistant pea germplasms with previously unknown er1 alleles, er1-1 was identified in seven germplasm accessions, er1-2 in 37, er1-6 in seven, and er1-7 in two (Tables 1 and 2).

Table 2. The distribution and numbers of pea germplasm accessions carrying er 1 alleles.

\begin{tabular}{|c|c|c|c|c|c|c|c|c|c|c|}
\hline \multirow{2}{*}{ Country } & \multicolumn{10}{|c|}{ No. of Pea Germplasm Accessions Contained er1 Alleles } \\
\hline & er1-1 & er1-2 & er1-3 & er1-4 & er1-5 & er1-6 & er1-7 & er1-8 & er1-9 & Total \\
\hline USA & - & 12 & - & - & - & 1 & - & - & - & 13 \\
\hline Canada & - & 4 & - & - & - & 1 & - & - & - & 5 \\
\hline Germany & - & 3 & - & - & - & - & - & - & - & 3 \\
\hline ICRISAT & - & 3 & - & - & - & - & - & - & - & 3 \\
\hline India & - & 1 & - & - & - & - & - & - & - & 1 \\
\hline Australia & 1 & 4 & - & - & - & - & - & - & 1 & 6 \\
\hline England & - & 1 & - & - & - & - & - & - & - & 1 \\
\hline Denmark & - & 1 & - & - & - & - & - & - & - & 1 \\
\hline Nepal & - & - & - & - & - & - & - & - & - & 0 \\
\hline Japan & - & 1 & - & - & - & - & - & - & - & 1 \\
\hline Afghanistan & - & - & - & - & - & - & - & 1 & - & 1 \\
\hline Mexico & 1 & - & - & - & - & - & - & - & - & 1 \\
\hline China & 3 & 5 & - & - & - & 5 & 2 & - & - & 15 \\
\hline $\begin{array}{l}\text { Unknown } \\
\text { country }\end{array}$ & 2 & 2 & - & - & - & - & - & - & - & 4 \\
\hline Total & 7 & 37 & - & - & - & 7 & 2 & 1 & 1 & 55 \\
\hline
\end{tabular}

Two novel er1 alleles were discovered in the two remaining germplasms: G0004389 (from Afghanistan) and G0004400 (from Australia). A novel mutation pattern was found in the G0004389 cDNA fragment homologous to PsMLO1: a 3-bp deletion (GTG) corresponding to positions 1339-1341 in exon 15 (the final exon) of the PsMLO1 cDNA sequence. This deletion caused the loss of the amino acid valine at position 447 of the PsMLO1 protein sequence, probably resulting in a functional change (Figure 1A). This mutation differed from all known er1 alleles, indicating that the E. pisi resistance of G0004389 was controlled by a novel allele of er1. This novel allele was designated er1-8, following the accepted nomenclature $[14,26,27,42,44,51]$. In pea germplasm G0004400, a 1-bp deletion (T) was identified in a previously unreported position homologous to position 928 in exon 10 of the PSMLO1 cDNA sequence. This deletion caused a substitution of the amino acid serine with leucine at position 
310 of the PsMLO1 protein sequence (Figure 1B). This change caused the early termination of protein translation, probably also resulting in a functional change of PsMLO1 (Figure 1B). Thus, E. pisi resistance in G0004400 was also controlled by a novel er1 allele, herein designated er1-9.

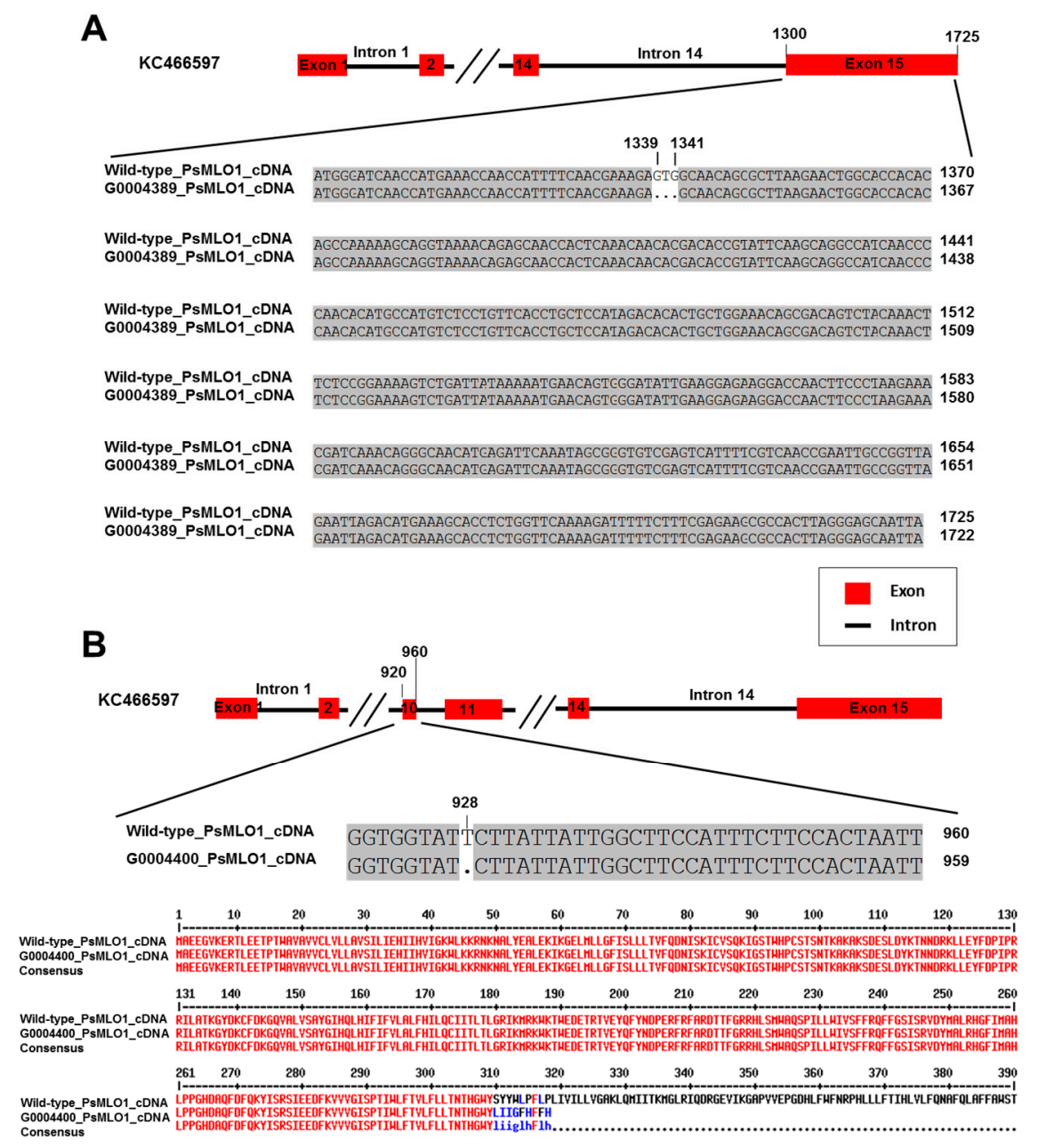

Figure 1. PSMLO1 cDNA sequences from the powdery mildew-resistant pea germplasms G0004389 and the wild-type pea cultivar Sprinter (GenBank accession number: FJ463618.1), and PsMLO1 cDNA sequences from G0004400 and amino acid sequence difference caused by mutation. (A) There is a 3-bp deletion (GTG) in the PsMLO1 cDNA of G0004389 at positions 1339-1341 of exon 15. (B), there is a single base deletion (T) in the PSMLO1 cDNA sequence of G0004400 at position 928 in exon 10, the lower figure shows the difference of amino acid sequence from G0004389 and the wild-type pea cultivar Sprinter. The two mutation sites are indicated in the respective cDNA sequences.

Interestingly, frame shift mutations, where small fragments are deleted or inserted, were identified in the cloned sequences of several pea germplasms. The fragments homologous to the wild-type PsMLO1 cDNA in seven pea germplasms (G0002602, G0006515, G0002883, G0004448, G0002848, G0003935, and G0005117) had 5-bp deletions (GTTAG) at positions 700-704 of wild-type PsMLO1 cDNA, while three pea germplasm accessions (G0002883, G0002971, and L0368) had another 5-bp deletion (TAGGG) at positions 1235-1239 of the wild-type PsMLO1 cDNA. In accession G0006514, there was a 4-bp deletion (GGAG) at positions 181-184 of the wild-type PsMLO1 cDNA. In four pea accessions (G0002847, G0004434, G0003974, and Texuan 11) and two pea accessions (G0002235 and G0002848), there were a 16-bp deletion (CTCATCTTCCTCCAGG) at positions 776-791 and a 16-bp insertion (AATTTTTCTGTTTCAG) at position 1171 of the wild-type PsMLO1 cDNA, respectively. In germplasm accession Jia 2, there was a 7-bp insertion (TAATAAG) at position 921 of the wild-type 
PsMLO1 cDNA. It was probable that these indels resulted from aberrant splicing events during transcription. Each frame shift mutation was observed in only one or two of ten cloned PsMLO1 cDNA sequences per germplasm accession.

Various alternative splicing patterns, including intron retention and exon skipping, were also observed in multiple PsMLO1 sequences cloned from the 55 resistant pea germplasm accessions. The eight introns retained were 1, 2, 4, 6, 7, 9, 12, and 13, and the three exons skipped were 4, 10, and 11 of the wild-type PsMLO1. Each intron retention and exon skipping event were discovered in only one or two of ten cloned PsMLO1 cDNA sequences.

\subsection{Genetic Analysis and Mapping of er1-8 and er1-9}

As expected, the two resistant pea parents, G0004389 and G0004400, were immune to E. pisi infection (disease severity 0), while the two susceptible parents (Bawan 6 and WSU 28) were heavily infected (disease severity 4) (Figure 2). The segregation patterns of E. pisi resistance in the $\mathrm{F}_{1}, \mathrm{~F}_{2}$, and $\mathrm{F}_{2: 3}$ populations derived from the crosses WSU $28 \times \mathrm{G} 0004389$ and Bawan $6 \times \mathrm{G} 0004400$ are presented in Table S1.
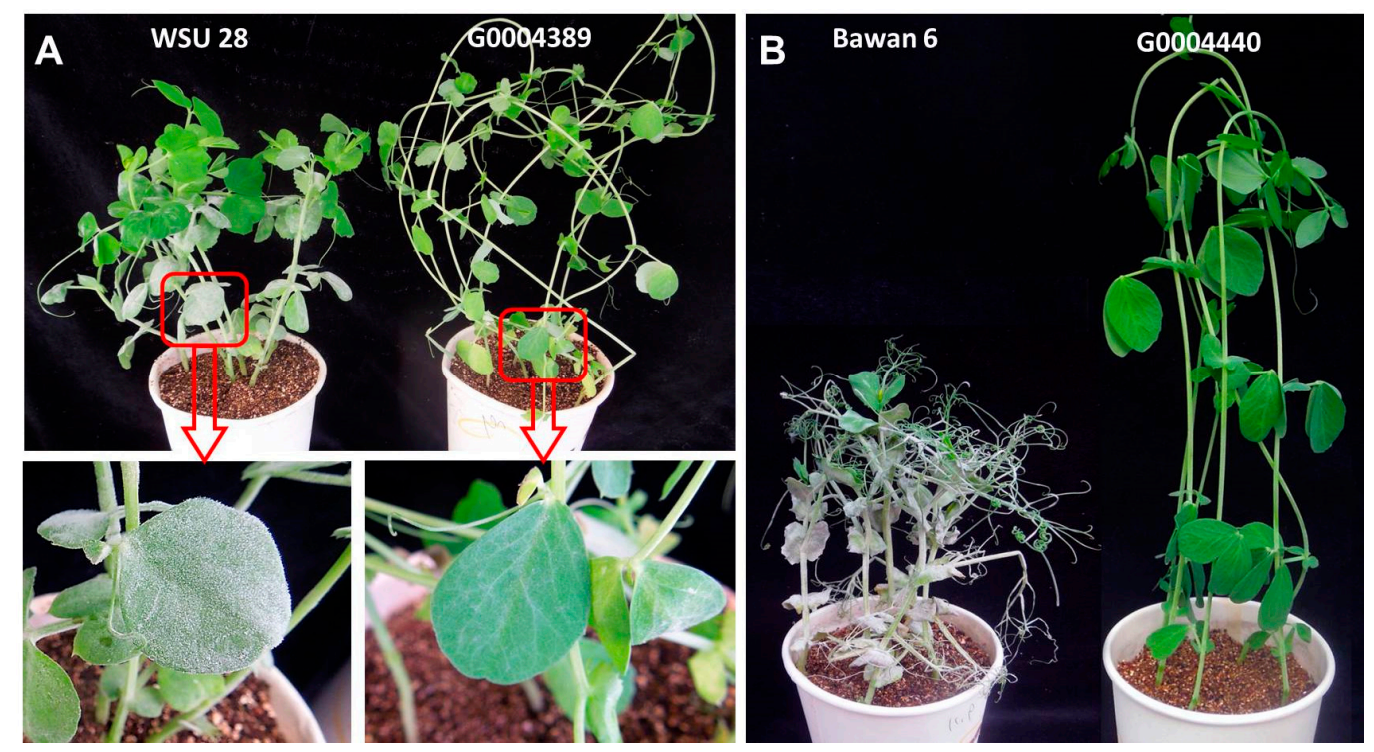

Figure 2. Phenotypic evaluation of the Erysiphe pisi-resistant pea germplasms G0004389 and G0004400, as well as the E. pisi-susceptible cultivars WSU 28 and Bawan 6, after inoculation with E. pisi isolate EPYN. (A) G0004389 and E. pisi-susceptible cultivar WSU 28. (B) G0004400 and E. pisi-susceptible cultivar Bawan 6.

Six $\mathrm{F}_{1}$ plants produced from the cross WSU $28 \times \mathrm{G} 0004389$ were susceptible to E. pisi (Table S1). One of the six plants generated $120 \mathrm{~F}_{2}$ and $\mathrm{F}_{2: 3}$ offspring through self-pollination. Of these $120 \mathrm{~F}_{2}$ plants, 30 were resistant $(\mathrm{R})$ to $E$. pisi, and 90 were susceptible (S) to E. pisi-. This indicates that the segregation ratio (resistance:susceptibility) in the $\mathrm{F}_{2}$ population was exactly $1: 3\left(\chi^{2}=0.01 ; P=0.92\right)$, indicating recessive heredity of a single gene. Moreover, a segregation ratio of 30 (homozygous resistant): 63 (segregating): 27 (homozygous susceptible) in the $\mathrm{F}_{2: 3}$ population fitted well with the genetic model of 1:2:1 ratio $\left(\chi^{2}=0.48, P=0.79\right)$ (Table S1), confirming that the E. pisi resistance in G0004389 was controlled by a single recessive gene.

The cross of Bawan $6 \times$ G0004400 generated five $F_{1}$ plants which showed E. pisi-susceptibility (Table S1). One of five $F_{1}$ plants generated $119 \mathrm{~F}_{2}$ offspring. 32 of 119 were resistant, and 87 of 119 were susceptible to $E$. pisi. The segregation ratio in the $\mathrm{F}_{2}$ population of resistance to susceptibility fitted a genetic model ratio of $1: 3\left(\chi^{2}=0.14 ; P=0.71\right)$, also indicating recessive heredity of a single gene. Moreover, a segregation ratio of 32 (homozygous resistant): 64 (segregating): 23 (homozygous 
susceptible) in the $\mathrm{F}_{2: 3}$ population (119 families) fitted well with the genetic model of 1:2:1 ratio $\left(\chi^{2}=\right.$ $2.51 ; P=0.29$ ), indicating that $E$. pisi resistance in $\mathrm{G} 0004400$ was also controlled by a single recessive gene (Table S1).

Of the 20 markers tested, five (c5DNAmet, AD160, AA200, AA224, and PSMPSA5) were polymorphic between parents WSU 28 and G0004389, and seven (AC74, AD160, PSMPSAD51, ScOPD10-650, ScOPX04-880, ScOPE16-1600, and AD59) were polymorphic between Bawan 6 and G0004400, indicating that these markers were likely linked to the E. pisi resistance gene. Thus, the five and the seven parental polymorphic markers were used to confirm the genotypes of each $\mathrm{F}_{2}$ plant derived from WSU $28 \times$ G0004389 and Bawan $6 \times$ G0004400, respectively. This genetic linkage analysis suggested that three markers (c5DNAmet, AA200, and AA224) and six markers (AD160, PSMPSAD51, ScOPD10-650, ScOPX04-880, ScOPE16-1600, and AD59) were linked to the resistance gene er1 in G0004389 and G0004400, respectively (Figure 3). Our results also indicated that the resistance genes in both germplasm accessions were located in the er1 region. In G0004389, the linkage map indicated that the markers (c5DNAmet and AA200) were mapped on both sides of the target gene with $9.6 \mathrm{cM}$ and $3.5 \mathrm{cM}$ genetic distances, respectively (Figure 3A). In G0004400, two other markers (PSMPSAD51 and ScOPX04-880) were located on both sides of the target gene with $12.2 \mathrm{cM}$ and $4.2 \mathrm{cM}$ genetic distances, respectively (Figure 3B). Our linkage and genetic map analyses confirmed that er1-8 and er1-9 controlled E. pisi resistance in G0004389 and G0004400, respectively (Figure 3).
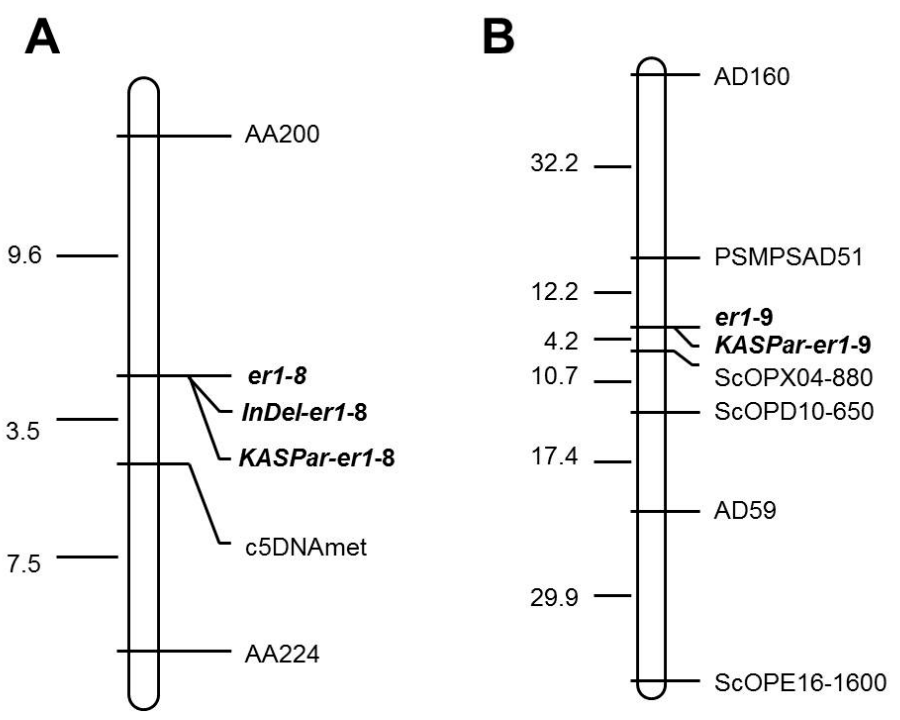

Figure 3. Genetic linkage maps constructed using the er1-linked markers and the functional markers for er1-8 and er1-9, based on the $\mathrm{F}_{2}$ populations derived from (A) WSU $28 \times$ G0004389 and (B) Bawan $6 \times$ G0004400. Map distances and loci order were determined with MAPMAKER v3.0 (Lander et al. 1993). Estimated genetic distances between loci are shown to the left of the maps in centiMorgans (cM).

\subsection{Development of Functional Markers for er1-8 and er1-9}

The indel marker, InDel-er1-8 flanking the 3-bp deletion in er1-8, amplified 231-bp and 228-bp fragments in the parents WSU 28 and G0004389, respectively. The amplicons were clearly polymorphic between the contrasting parents, as visualized on an $8 \%$ polyacrylamide gel (Figure S1A). InDel-er1-8 was then used to identify the genotypes of the $120 \mathrm{~F}_{2}$ plants derived from WSU $28 \times \mathrm{G} 0004389$. Three distinct electrophoretic bands corresponding to the homozygous resistant $(\mathrm{R})$, homozygous susceptible $(\mathrm{S})$, and heterozygous $(\mathrm{H})$ genotypes were observed (Figure $\mathrm{S} 1 \mathrm{~A}$ ). Each $\mathrm{F}_{2}$ genotype corresponded to a phenotype of the $120 \mathrm{~F}_{2: 3}$ families. A chi-squared $\left(\chi^{2}\right)$ test showed that the segregation ratio of InDel-er1-8 in the $\mathrm{F}_{2: 3}$ population derived from WSU $28 \times$ G0004389 fit a 1:2:1 $\left(\chi^{2}=0.48 ; P=\right.$ 0.79). All results suggested that the marker InDel-er1-8 co-segregated with gene er 1-8, indicating a co-dominant marker. 
In the Kompetitive allele-specific PCR (KASPar) assay, KASPar-er1-8 and KASPar-er1-9 successfully distinguished the contrasting parents (WSU 28 and G0004389, Bawan 6 and G0004400) into two different clusters corresponding to the FAM-labeled and HEX-labeled groups, respectively (Figure S2). When KASPar-er1-8 and KASPar-er1-9 were used to analyze the 120 and $119 \mathrm{~F}_{2}$ progeny derived from WSU $28 \times$ G0004389 and Bawan $6 \times$ G0004400, the KASPar markers clearly separated the $F_{2}$ progeny into three clusters corresponding to three genotypes: homozygous resistant, homozygous susceptible, and heterozygous (Figure S2). In the $\mathrm{F}_{2}$ population derived from WSU $28 \times \mathrm{G} 0004389$, 30 plants were identified as homozygous resistant, 63 were heterozygous, and 27 were homozygous susceptible. In the $F_{2}$ population derived from Bawan $6 \times$ G0004400, 32 plants were homozygous resistant, 64 were heterozygous, and 23 were homozygous susceptible. These results were completely consistent with the phenotypes of both $\mathrm{F}_{2: 3}$ populations, suggesting that KASPar-er1-8 and KASPar-er1-9 co-segregated with er1-8 and er1-9, respectively. A chi-squared $\left(\chi^{2}\right)$ test showed that both segregation ratios of KASPar-er1-8 and KASPar-er1-9 in respective $F_{2}$ populations fit 1:2:1 (KASPar-er1-8: $\chi^{2}=0.48, P=0.79$; KASPar-er1-9: $\left.\chi^{2}=2.51 ; P=0.29\right)$, indicating co-dominant markers.

\subsection{Validation and Application of Functional Markers}

Of the 169 germplasm accessions selected and tested for their phenotypic resistance to E. pisi isolate EPYN (Table S2), 19 were phenotypically immune to E. pisi, 22 were resistant, and 128 were susceptible (Table S2).

Among the 169 germplasms genotyped with InDel-er1-8, the 228-bp fragment corresponding to er1-8 was only amplified in G0004839 (Figure S1B). In all of the other tested germplasm accessions, a 231-bp fragment was consistently amplified by InDel-er1-8, indicating that no accessions besides G0004839 carried er1-8 (Figure S1B; Table S1).

When the 169 germplasm accessions were genotyped with KASPar-er1-8, two distinct clusters were recovered, with one gene (er1-8) corresponding to G0004389 and the other (non-er1-8) to the other germplasms, respectively. Similarly, when the germplasms were genotyped with KASPar-er1-9, two distinct clusters were recovered, corresponding to G0004400 and all of the other germplasms, respectively (Figure S2; Table S1). Thus, markers KASPar-er1-8 and KASPar-er1-9 effectively identified pea germplasms carrying the er1-8 and er1-9 alleles, respectively. Our results also showed that none of the other 169 pea germplasm accessions carried the er1-8 or er1-9 alleles.

\section{Discussion}

Powdery mildew induced by E. pisi DC. is a major disease on pea and causes considerable yield losses worldwide. The resistance gene er 1 is the most widely deployed gene controlling powdery mildew in pea cultivars worldwide. Furthermore, er 1 allelic diversity has been widely reported in pea $[14,21,25-27,38,40-44,51]$.

To date, more than 40 MLO mutant alleles have been described in the monocotyledonous plant barley [52]. It is predicted that additional er 1 alleles resulting from natural mutations would be present among pea germplasms from around the world. As expected, we not only encountered the four known er1 alleles (er1-1, er1-2, er1-6, and er1-7) across the 53 E. pisi-resistant pea germplasms, but we also discovered two novel er1 alleles: er1-8 in germplasm G0004389 from Afghanistan and er1-9 in germplasm G0004400 from Australia (Table 1).

Among the nine known er1 alleles, er1-1 and er1-2 are most commonly used in pea breeding programs because they confer stable resistance to E. pisi $[14,25,38,51]$. Our results indicated that these two alleles were common in the tested pea germplasm accessions resistance to E. pisi. The er1-1 allele was found in seven accessions (12.73\%), and er1-2 was found in 37 accessions (67.27\%) (Table 2). Among the 86 E. pisi-resistant pea accessions, er1-1 and er1-2 were identified in $10(11.62 \%)$ and 42 $(48.84 \%)$ accessions, respectively (Table 1). Previously, er1-1 has been identified in four E. pisi-resistant pea cultivars (JI1559, Tara, and Cooper from Canada; and Yunwan 8 from China), while er1-2 has been identified in seven E. pisi-resistant pea cultivars (Stratagem, Franklin, Dorian, Nadir, X9002, Xucai 1, 
and G0005576) $[14,24,25,27,38]$. Here, more E. pisi-resistant germplasm accessions carrying the er $1-1$ and er1-2 alleles were identified.

At the genomic level, seven alleles (er1-1/er1mut1, er1-3, er1-4, er1-5, er1-6, er1-9, and er1-10/er1mut2) are the result of point mutations in the exons of wild-type PSMLO1. Four alleles result from single base substitutions in wild-type PsMLO1 cDNA: in er1-1, a C $\rightarrow \mathrm{G}$ at position 680 (exon 6); in er1-5, a $\mathrm{G} \rightarrow \mathrm{A}$ at position 570 (exon 5); in $e r 1-6$, a $\mathrm{T} \rightarrow \mathrm{C}$ at position 1121 (exon 11); and in er1-10, a $\mathrm{G} \rightarrow \mathrm{A}$ at position 939 (exon 10) (Figure S3) $[14,27,38,40]$. Three alleles result from single base deletions in wild-type $P_{S} M L O 1 \mathrm{cDNA}$, including $\triangle \mathrm{G}$ at position 862 (exon 8) in er1-3; $\triangle \mathrm{A}$ at position 91 (exon 1) in er1-4; and $\Delta \mathrm{T}$ at position 928 (exon 10) in er1-9 identified in this study [14] Two alleles result from small fragment deletions in wild-type PsMLO1 cDNA, including a 10-bp deletion of positions 111-120 (exon 1) in er1-7 [26]; and a 3-bp deletion of positions 1339-1341 (exon 15) in er1-8. To date, only the er1-11 mutation is known to have resulted from an intron mutation in PsMLO1 (a 2-bp insertion in intron 14) [42,43], and only er1-2 results from a large indel of unknown size in wild-type PsMLO1 cDNA $[14,24,27]$.

Previous studies have indicated that the er1-2 allele produces three distinct PSMLO1 transcripts $[14,25,27,51]$. Interestingly, this study observed that the er $1-2$ carried by the pea germplasm accession G0002860 produced four distinct PsMLO1 transcripts. One of these transcripts was characterized by a 129-bp deletion, corresponding to the deletion of exon 13 (68 bp) and exon 14 (61 bp) from wild-type PsMLO1 cDNA, indicating alternative splicing of exon skipping. Previously, two transcripts of er1-2 were observed to have large insertions (155-bp and 220-bp) based on comparisons with the transcripts of wild-type PsMLO1 cDNA [14,24,25,27,51]. Here, we discovered that the 155-bp "insertion" in er1-2 resulted from a 192-bp insertion at position 1263 and a 37-bp deletion of positions 1263-1299 in exon 14 of wild-type PSMLO1, while the 220-bp "insertion" resulted from a 257-bp insertion at position 1263 and a 37-bp deletion of positions 1263-1299 in exon 14 of wild-type PsMLO1. Another alternative transcript of er1-2, an 87-bp "insertion", was observed and resulted from a 192-bp insertion and a 37-bp deletion in exon 14 and a 68-bp deletion corresponding to exon 13 of wild-type PsMLO1. Our blast analysis indicated that the 192- and 257-bp insertions had 95\% sequence identity with a five-part repetition in the pea genomic BAC sequence (GenBank accession number CU655882). These insertions were also highly similar ( 85-87\% identity) to a portion of the giant Ogre retrotransposons in the pea genome (GenBank accession numbers AY299395, AY299398, AY299397, and AY299394).

Based on 10 cloned sequences, several pea germplasms had frame shift mutations with small fragment indels (4-bp, 5-bp, or 16-bp) in one or two cloned PSMLO1 cDNA sequences. Previously, a 5-bp (GTTAG) insertion was identified in G0001763 and G0003831; 11-bp (GTAGGAATAAG) and 13-bp (GTAATCTTATTAG) deletions were identified in G0003831 and G0001778; and a 16-bp (CTCATCTTCCTCCAGG) deletion was detected in G0001778 [27]. These small fragment indels in the PSMLO1 cDNAs were assumed to have resulted from aberrant splicing events during transcription [27].

Alternative splicing in eukaryotes is a pervasive molecular mechanism that significantly increases transcriptome and proteome complexity [53]. Four main types of alternative splicing are known: exon skipping, alternative $5^{\prime}$ splice sites, alternative $3^{\prime}$ splice sites, and intron retention [54]. Exon skipping is common in humans, while intron retention is common in plants [55]. Alternative splicing is involved in many physiological processes, including response to biotic and abiotic stressors [56]. In the pea germplasms, three types of alternative splicing, intron retention, exon skipping, and alternative $5^{\prime}$ splice site selection, were observed in this study. Interestingly, pea germplasms carrying identical er 1 alleles varied in their resistance to E. pisi, from immune (disease severity of 0 ) to merely resistant (disease severity of 1-2) (Table 1). Alternative splicing in response to biotic stress may affect the expression of regulatory genes. Thus, it is speculated that the alternative splicing of er 1 alleles might affect the expression of the E. pisi resistance genes er1. In addition, the different levels of resistance to $E$. pisi might result from other related gene regulation. It is possible that multiple molecular processes and pathways contribute to MLo-based E. pisi resistance in peas. 
Several functional markers specific to the previously recognized er 1 alleles have already been developed to facilitate marker-assisted breeding of pea cultivars resistant to E. pisi $[14,24,26,27,40,42-44]$. Pavan et al. [38] developed a functional cleaved amplified polymorphic sequence (CAPS) marker for er1-5, while Pavan et al. [44] developed functional markers for the five er1 alleles, er1-1 through er1-5. Santo et al. [40] developed functional markers for er1mut1 and er1mut2, and Wang et al. [24] developed a dominant marker for er1-2. Sudheesh et al. [43] developed a functional marker for er1-11, while Sun et al. [26,27] developed co-dominant functional markers for er1-6 and er1-7. More recently, Ma et al. [42] developed eight KASPar markers for eight known er1 alleles, excluding er1-2.

This study discovered two novel er 1 alleles resulting from novel mutations of wild-type PSMLO1 cDNA: er1-8 was generated by a 3-bp deletion in exon 15, and er1-9 was generated by a 1-bp deletion in exon 10. The co-dominant functional markers specific to er1-8 (InDel-er1-8 and KASPar-er1-8) and to er1-9 (KASPar-er1-9) were developed. These markers were validated in genetic populations and in pea germplasms. Our results are vital for future studies of powdery mildew resistance and for the development of E. pisi-resistant pea cultivars. The novel er1 alleles and the corresponding co-dominant functional markers developed herein could constitute efficient and powerful tools for the breeding of E. pisi-resistant peas.

\section{Materials and Methods}

\subsection{Plant Material and E. pisi Isolate}

Previously, 86 pea germplasms had been found to be E. pisi-resistant in screenings of over 1000 pea accessions in a worldwide collection $[27,48,50]$. And, 31 of 86 resistant pea germplasms had been previously identified the E. pisi-resistant er1 allele [24-27,48,51]. In this study, the remaining 55 of the 86 E. pisi-resistant pea germplasms from the United States of America, Canada, Germany, India, Australia, Columbia, England, Denmark, Nepal, Japan, Afghanistan, and Mexico, as well as data from the International Crop Research Institute for Semi-arid Tropics (ICRISAT) and conserved in the China National Genebank (http://www.cgris.net/), were used as research materials to reveal their E. pisi-resistant genes at er 1 locus (Table 1). The Chinese pea cultivars Bawan 6 and Longwan 1, which carry the E. pisi-susceptible gene Er1, were used as susceptible controls [24,51]. The Chinese pea cultivars Xucai 1, carrying er1-2, and YI (JI1591), carrying er1-4, were used as E. pisi-resistant controls [14,25].

The E. pisi isolate EPYN from Yunnan Province of China was used as the inoculum $[26,27,41,48,50,51]$. The EPYN isolate was maintained through continuous re-inoculation of seedlings of the pea cultivar Longwan 1 under controlled conditions. The inoculated plants were incubated in a growth chamber to prevent contamination with other isolates [25].

\subsection{Phenotypic Evaluation}

Twenty seeds were planted from each of the 55 E. pisi-resistant pea germplasm accessions, from the susceptible controls Bawan 6 and Longwan 1, and from the resistant controls Xucai 1 and YI [27]. The seedlings were thinned to 15 per pot before the phenotypic evaluation. Three replications were planted. Seeded pots were placed in a greenhouse maintained at 18 to $26^{\circ} \mathrm{C}$. At the same time, the $E$. pisi inoculum was prepared by inoculating the 10-day-old seedlings of the susceptible pea cultivar Longwan 1, which were incubated in a growth chamber at $20 \pm 1{ }^{\circ} \mathrm{C}$ with a 12 -h photoperiod. Two weeks later, the 14-day-old seedlings of 55 germplasm accessions and controls were inoculated by gently shaking off conidia of the Longwan 1 plants. Inoculated plants were incubated in a growth chamber at $20 \pm 1{ }^{\circ} \mathrm{C}$ with a 12 -h photoperiod. Ten days later, disease severity was rated based on a scale ( $0-4$ scale) [27]. Plants with a score of 0 were considered E. pisi-immune, while those with scores of 1 and 2, 3 and 4 were considered as E. pisi-resistant and E. pisi-susceptible, respectively. For those identified as immune or resistant to E. pisi, repeated identification was performed. 


\subsection{RNA Extraction and PsMLO1 Sequence Analysis}

The extraction of total RNA and synthesis of cDNA from the 55 pea germplasms and controls were completed according to our previous studies [25-27].

To identify the resistance alleles at the er1 loci, the full-length cDNAs of the PsMLO1 homologs were amplified using the primers specific for PsMLO1 [14]. The PCR cycling conditions were as follows: $95^{\circ} \mathrm{C}$ for $5 \mathrm{~min}$; then 35 cycles of denaturation at $94^{\circ} \mathrm{C}$ for $30 \mathrm{~s}$, annealing at $58^{\circ} \mathrm{C}$ for $45 \mathrm{~s}$, and extension at $72{ }^{\circ} \mathrm{C}$ for $1 \mathrm{~min}$; and a final extension at $72{ }^{\circ} \mathrm{C}$ for $10 \mathrm{~min}$. The purified amplicons were cloned with a pEasy-T5 vector (TransGen Biotech, Beijing, China). The sequencing reactions of 10 clones per germplasm (including controls) were performed by the Shanghai Shenggong Biological Engineering Co., Ltd. (Shanghai, China). The resulting sequences were aligned with wild-type PSMLO1 of pea (NCBI accession number: FJ463618.1) using DNAMAN v6.0 (Lynnon Biosoft, Quebec, Canada).

\subsection{Genetic Analysis of Pea Germplasms Carrying Novel Alleles}

To confirm the resistance genes, er1-8 and er1-9, G0004389 and G0004400 were crossed with the E. pisi-susceptible cultivars WSU 28 and Bawan 6, respectively, to generate genetic populations. The derived $F_{1}, F_{2}$, and $F_{2: 3}$ populations from both crosses (WSU $28 \times \mathrm{G} 0004389$ and Bawan $6 \times$ G0004400) were used to evaluate the E. pisi resistance and genetic analysis of G0004389 and G0004400. The four parents and the derived $F_{1}$ and $F_{2}$ populations were planted in a propagation greenhouse to generate $\mathrm{F}_{2}$ and $\mathrm{F}_{2: 3}$ family seeds, respectively.

Plants of the F2 populations at the fourth or fifth leaf stage were inoculated with the E. pisi isolate EPYN using the detached leaf method [25-27,57]. After inoculation, the treated leaves were placed in a growth chamber at $20^{\circ} \mathrm{C}$ with a 14-h photoperiod. The four parents (WSU 28, G0004389, Bawan 6 , and G0004400) were also inoculated as controls. Ten days after inoculation, disease severity was rated based on a scale of $0-4$ as described above. Plants with scores of $0-2$ and 3-4 were classified as resistant and susceptible, respectively [25-27,31,58]. Those plants identified as E. pisi-resistant were tested again to confirm their resistance.

Twenty-five seeds were selected randomly from each of the $120 \mathrm{~F}_{2: 3}$ families derived from WSU 28 $\times \mathrm{G} 0004389$, and from each of the $119 \mathrm{~F}_{2: 3}$ families derived from Bawan $6 \times \mathrm{G} 0004400$. These seeds were planted and cultivated together with their parents, following previously published protocols [25-27]. Disease severity was scored 10 days after inoculation using the $0-4$ scale, as described above for the phenotypic identification of the pea germplasms. The $\mathrm{F}_{2: 3}$ families with scores of $0-2$ and 3-4 were classified as homozygous resistant and homozygous susceptible, respectively. Families with scores of $0-2$ and 3-4 were considered segregated to E. pisi resistance $[27,31,58]$. The families identified as homozygous resistant or resistance segregated were subjected to repeated testing.

A chi-squared $\left(\chi^{2}\right)$ analysis was used to evaluate the goodness-of-fit to Mendelian segregation ratio of the $F_{2}$ and $F_{2: 3}$ phenotypes derived from WSU $28 \times$ G0004389 and Bawan $6 \times$ G0004400.

\subsection{Genetic Mapping of the Resistance Alleles er1-8 and er1-9}

The Genomic DNA was isolated from the leaves of the $\mathrm{F}_{2}$ populations and of their parents using the cetyltrimethylammonium bromide (CTAB) extraction method [59]. The DNA solution was diluted and stored at $-20^{\circ} \mathrm{C}$ until use.

To map the novel er1 alleles er1-8 and er1-9, the 10 known er1-linked markers on the pea LG VI, including four sequence-characterized amplified region (SCAR) markers [ScOPD10-650 [17], ScOPE16-1600 [18], ScOPO18-1200 [18], and ScOPX04-880 [23]; five simple sequence repeat (SSR) markers (PSMPSAD51, PSMPSA5, PSMPSAD60, i.e., AD60, PSMPSAA374e, and PSMPSAA369); a gene marker [Cytosine-5, DNA-methyltransferase (c5DNAmet)] [20,24-27,48,60]; and 10 additional molecular markers on the pea LG VI (AD160, AC74, AC10_1, AA224, AA200, AD159, AD59, AB71, AA335, and AB86), were used to screen for polymorphisms between the crossed parents (i.e., WSU 28 and G0004389; Bawan 6 and G0004400) [61]. The parental polymorphic markers were then used for 
genetic linkage analysis based on the genotype of each $\mathrm{F}_{2}$ plant. PCR amplification of each marker was conducted in a total volume of $20 \mu \mathrm{L}$ according to the previous descriptions [25-27]. PCR reactions were performed in a thermal cycler (Biometra, Göttingen, Germany) [25-27]. The PCR products were separated on $6 \%$ polyacrylamide gels.

The segregation data of the polymorphic markers in the $F_{2}$ populations were evaluated for goodness-of-fit to Mendelian segregation patterns with a chi-squared $\left(\chi^{2}\right)$ test. Genetic linkage analyses were completed using MAPMAKER/EXP version 3.0b. A logarithm of odds (LOD) score $>3.0$ and a distance $<50 \mathrm{cM}$ were used as the thresholds to determine the linkage groups [62]. Genetic distances were determined using the Kosambi mapping function [63]. The genetic linkage map was constructed using the Microsoft Excel macro MapDraw [64].

\subsection{Development of Functional Markers for er1-8 and er1-9}

Primers flanking the mutation site (GTG/-) were designed based on the PSMLO1 gene sequence (GenBank accession number KC466597), using Primer Premier v5.0, to develop an insertion/deletion (indel) functional marker specific to allele er1-8, InDel-er1-8 (Table 3). The marker InDel-er1-8 was used to determine the genotypes of the $120 \mathrm{~F}_{2}$ offspring derived from WSU $28 \times \mathrm{G} 0004389$. PCR amplification was performed as described above on a thermal cycler with the following cycling program: $95^{\circ} \mathrm{C}$ for $5 \mathrm{~min} ; 35$ cycles of $94{ }^{\circ} \mathrm{C}$ for $30 \mathrm{~s}, 55^{\circ} \mathrm{C}$ for $30 \mathrm{~s}$, and $72{ }^{\circ} \mathrm{C}$ for $30 \mathrm{~s}$; and $72{ }^{\circ} \mathrm{C}$ for $7 \mathrm{~min}$. PCR products were separated on $8 \%$ polyacrylamide gels.

Table 3. Sequence information for the indel and Kompetitive allele-specific PCR (KASPar) markers specific to er1-8, and for the KASPar marker specific to er1-9.

\begin{tabular}{cccc}
\hline Markers & Primers & Sequence Information $\left(5^{\prime}-3^{\prime}\right)$ & Annealing $\mathbf{~ T m}$ \\
\hline InDel-er1-8 & Forward & GTTTTGACTGATATGACAGATGGGA & $55^{\circ} \mathrm{C}$ \\
& Reverse & GTTTGAGACTGTCGCTGTTCC & \\
KASPar-er1-8 & Forward-TGG & TGGCAACAGCGCTTAAGAACTGG & $65-57^{\circ} \mathrm{C}$ touchdown \\
& Forward & GAGCAACAGCGCTTAAGAACTGG & \\
& Common reverse & TGGTTGGTTTCATGGTTGATCCCATC & \\
KASPar-er1-9 & Forward-T & TTTTGTTATATGGGCAGGGTGGTATT & $65-57^{\circ} \mathrm{C}$ touchdown \\
& Forward & TGTTATATGGGCAGGGTGGTATC & \\
& Common reverse & CAAAATGTAGATTATGCTTACAATTAGTGGA & \\
\hline
\end{tabular}

Based on allele er1-8 indels (a 3-bp deletion) and er1-9 SNPs (1-bp deletion) in PsMLO1, the forward primers and the common reverse primers specific to er1-8 (KASPar-er1-8) and er1-9 (KASPar-er1-9) were designed for Kompetitive allele-specific PCR (KASPar) markers by LGC KBioscience (KBioscience, Hoddesdon, UK), respectively. In brief, two KASPar markers (KASPar-er1-8 and KASPar-er1-9) were used to detect parental polymorphisms (WSU $28 \times$ G0004389, and Bawan $6 \times$ G0004400), and then used to analyze the genotypes of the $F_{2}$ offspring (WSU $28 \times$ G0004389: $120 F_{2}$ individuals; Bawan $6 \times$ G0004400: $119 \mathrm{~F}_{2}$ individuals).

KASPar markers were amplified with a Douglas Scientific Array Tape Platform (China Golden Marker, Beijing, Biotech Co., Ltd.) in a $0.8 \mu \mathrm{L}$ Array Tape reaction volume with $10 \mathrm{ng}$ dry DNA, $0.8 \mu \mathrm{L} 2$ $\times$ KASP master mix, and $0.011 \mu \mathrm{L}$ primer mix (KBioscience, Hoddesdon, UK). A Nexar Liquid handling instrument was used to add the PCR solution to the Array Tape (Douglas Scientific). PCRs were performed on a Soellex PCR Thermal Cycler with the following conditions: initial denaturation at $94^{\circ} \mathrm{C}$ for $15 \mathrm{~min}$; followed by 10 cycles of denaturation at $94{ }^{\circ} \mathrm{C}$ for $20 \mathrm{~s}$, and $65^{\circ} \mathrm{C}$ for $60 \mathrm{~s}$ at an annealing temperature that decreased by $0.8^{\circ} \mathrm{C}$ per cycle; and then 26 cycles of denaturation at $94{ }^{\circ} \mathrm{C}$ for $20 \mathrm{~s}$ and $57^{\circ} \mathrm{C}$ for $60 \mathrm{~s}$; and a final cooling to $4{ }^{\circ} \mathrm{C}$. A fluorescent end-point reading was completed with the Araya fluorescence detection system (part of the Douglas Scientific Array Tape Platform). Genotypes and clusters were visualized with Kraken (http://ccb.jhu.edu/software/kraken/MANUAL.html). 


\subsection{Validation and Application of Functional Markers}

To test the efficacy of the novel functional markers specific to er1-8 (InDel-er1-8 and KASPar-er1-8) and er1-9 (KASPar-er1-9), 169 pea germplasm accessions were tested for (a) their phenotypic resistance to E. pisi isolate EPYN and (b) whether they carried the er1 alleles er1-8 or er1-9 (Table S2). The four parent cultivars (WSU 28, G0004389, Bawan 6, and G0004400) were used as contrasting controls, and seven cultivars, including Tara (er1-1) [41], Xucai 1 (er1-2) [25], JI210 (er1-3) [14], YI (er1-4) [14], G0001778 (er1-6) [27], DDR11 (er1-7) [26], and GI2480 (er2) [28], were used as positive controls (Table S2).

DNA was extracted from the 169 selected pea germplasm accessions and the 11 controls (four parents and seven resistant cultivars with known er 1 alleles) using the CTAB method (Shure et al. 1983). PCR amplifications of the indel and KASPar markers were performed as described above (in the section "Development of functional er1-8 and er1-9 markers").

Supplementary Materials: Supplementary materials can be found at http://www.mdpi.com/1422-0067/20/20/ 5071/s1.

Author Contributions: Z.Z. conceived and designed the experiments. S.S., D.D., C.D., X.Z., D.X., and Y.H. performed the experiments. S.S. analyzed the data and wrote the manuscript. Z.Z. revised the manuscript. All authors read and approved the manuscript.

Funding: This study was supported by the Modern Agro-industry Technology Research System (CARS-09) and the Crop Germplasm Conservation and Utilization Program from the Ministry of Agriculture of China (2019NWB030-12), the National Infrastructure for Crop Germplasm Resources (NICGR2019-008), and the Scientific Innovation Program of the Chinese Academy of Agricultural Sciences from the Institute of Crop Sciences, Chinese Academy of Agricultural Sciences.

Acknowledgments: We sincerely thank Clarice J. Coyne (Plant Germplasm Introduction and Testing, USDA ARS, Pullman, WA 99164, USA) and Rebecca J. McGee (Grain Legume Genetics and Physiology Research Unit, USDA ARS, Pullman, WA 99164, USA) for providing the pea germplasm WSU 28.

Conflicts of Interest: The authors declare no conflict of interest.

\section{Abbreviations}

$\begin{array}{ll}\text { SSR } & \text { Simple sequence repeat } \\ \text { SNP } & \text { Single nucleotide polymorphism } \\ \text { InDel } & \text { Insertion/deletion } \\ \text { KASPar } & \text { Kompetitive allele-specific PCR }\end{array}$

\section{References}

1. Ali, S.M.; Sharma, B.; Ambrose, M.J. Current status and future strategy in breeding pea to improve resistance to biotic and abiotic stresses. Euphytica 1993, 1, 115-126.

2. Wang, X.; Zhu, Z.; Duan, C.; Zong, X. Identification and Control Technology of Disease and Pest on Faba Bean and Pea; Chinese Agricultural Science and Technology Press: Beijing, China, 2007.

3. Gritton, E.T.; Ebert, R.D. Interaction of planting date and powdery mildew on pea plant performance. Am. Soc. Horti. Sci. 1975, 100, 137-142.

4. Peng, H.X.; Yao, G.; Jia, R.L.; Liang, H.Y. Identification of pea germplasm resistance to powdery mildew. J. Southwest Agric. Univ. 1991, 13, 384-386. (In Chinese)

5. Smith, P.H.; Foster, E.M.; Boyd, L.A.; Brown, J.K.M. The early development of Erysiphe pisi on Pisum sativum L. Plant. Pathol. 1996, 45, 302-309. [CrossRef]

6. Ghafoor, A.; McPhee, K. Marker assisted selection (MAS) for developing powdery mildew resistant pea cultivars. Euphytica 2012, 186, 593-607. [CrossRef]

7. Fondevilla, S.; Rubiales, D. Powdery mildew control in pea, a review. Agron. Sustain. Dev. 2012, 32, 401-409. [CrossRef]

8. Ondřej, M.; Dostálová, R.; Odstrčilová, L. Response of Pisum sativum germplasm resistant to Erysiphe pisi to inoculation with Erysiphe baeumleri, a new pathogen of peas. Plant. Prot. Sci. 2005, 41, 95-103. [CrossRef]

9. Attanayakea, R.N.; Glaweab, D.A.; McPheec, K.E.; Dugand, F.M.; Chend, W. Erysiphe trifolii-A newly recognized powdery mildew pathogen of pea. Plant. Pathol. 2010, 59, 712-720. [CrossRef] 
10. Fondevilla, S.; Chattopadhyay, C.; Khare, N.; Rubiales, D. Erysiphe trifolii is able to overcome er1 and Er3, but not er2, resistance genes in pea. Eur. J. Plant. Pathol. 2013, 136, 557-563. [CrossRef]

11. Harland, S.C. Inheritance of immunity to mildew in Peruvian forms of Pisum sativum. Heredity 1948, 2, 263-269. [CrossRef]

12. Heringa, R.J.; Van Norel, A.; Tazelaar, M.F. Resistance to powdery mildew (Erysiphe polygoni D.C.) in peas (Pisum satioum L.). Euphytica 1969, 18, 163-169. [CrossRef]

13. Fondevilla, S.; Torres, A.M.; Moreno, M.T.; Rubiales, D. Identification of a new gene for resistance to powdery mildew in Pisum fulvum, a wild relative of pea. Breed. Sci. 2007, 57, 181-184. [CrossRef]

14. Humphry, M.; Reinstädler, A.; Ivanov, S.; Bisseling, T.; Panstruga, R. Durable broad-spectrum powdery mildew resistance in pea er1 plants is conferred by natural loss-of-function mutations in PsMLO1. Mol. Plant. Pathol. 2011, 12, 866-878. [CrossRef] [PubMed]

15. Sarala, K. Linkage Studies in Pea (Pisum sativum L.) with Reference to Er Gene for Powdery Mildew Resistance and Other Genes. Ph.D. Thesis, Indian Agricultural Research Institute, New Delhi, India, 1993.

16. Dirlewanger, E.; Isaac, P.G.; Ranade, S.; Belajouza, M.; Cousin, R.; Vienne, D. Restriction fragment length polymorphism analysis of loci associated with disease resistance genes and developmental traits in Pisum sativum L. Theor. Appl. Genet. 1994, 88, 17-27. [CrossRef]

17. Timmerman, G.M.; Frew, T.J.; Weeden, N.F. Linkage analysis of er1, a recessive Pisum sativum gene for resistance to powdery mildew fungus (Erysiphe pisi DC). Theor. Appl. Genet. 1994, 88, 1050-1055. [CrossRef]

18. Tiwari, K.R.; Penner, G.A.; Warkentin, T.D. Identification of coupling and repulsion phase RAPD markers for powdery mildew resistance gene er1 in pea. Genome 1998, 41, 440-444. [CrossRef]

19. Janila, P.; Sharma, B. RAPD and SCAR markers for powdery mildew resistance gene er in pea. Plant. Breed. 2004, 123, 271-274. [CrossRef]

20. Ek, M.; Eklund, M.; von Post, R.; Dayteg, C.; Henriksson, T.; Weibull, P.; Ceplitis, A.; Isaac, P.; Tuvesson, S. Microsatellite markers for powdery mildew resistance in pea (Pisum sativum L.). Hereditas 2005, 142, 86-91. [CrossRef]

21. Pereira, G.; Marques, C.; Ribeiro, R.; Formiga, S.; Dâmaso, M.; Sousa, T.; Farinhó, M.; Leitão, J.M. Identification of DNA markers linked to an induced mutated gene conferring resistance to powdery mildew in pea (Pisum sativum L.). Euphytica 2010, 171, 327-335. [CrossRef]

22. Tonguc, M.; Weeden, N.F. Identification and mapping of molecular markers linked to er1 gene in pea. J. Plant. Mol. Biol. Biotech. 2010, 1, 1-5.

23. Srivastava, R.K.; Mishra, S.K.; Singh, K.; Mohapatra, T. Development of a coupling-phase SCAR marker linked to the powdery mildew resistance gene er1 in pea (Pisum sativum L.). Euphytica 2012, 86, 855-866. [CrossRef]

24. Wang, Z.; Fu, H.; Sun, S.; Duan, C.; Wu, X.; Yang, X.; Zhu, Z. Identification of powdery mildew resistance gene in pea line X9002. Acta Agron. Sin. 2015, 41, 515-523, (In Chinese with English abstract). [CrossRef]

25. Sun, S.; Wang, Z.; Fu, H.; Duan, C.; Wang, X.; Zhu, Z. Resistance to powdery mildew in the pea cultivar Xucai 1 is conferred by the gene er1. Crop. J. 2015, 3, 489-499. [CrossRef]

26. Sun, S.; Deng, D.; Wang, Z.; Duan, C.; Wu, X.; Wang, X.; Zong, X.; Zhu, Z. A novel er1 allele and the development and validation of its functional marker for breeding pea (Pisum sativum L.) resistance to powdery mildew. Appl. Genet. 2016, 129, 909-919.

27. Sun, S.; Fu, H.; Wang, Z.; Duan, C.; Zong, X.; Zhu, Z. Discovery of a novel er1 allele conferring powdery mildew resistance in Chinese pea (Pisum sativum L.) landraces. PLoS ONE 2016, 11, e0147624. [CrossRef]

28. Katoch, V.; Sharma, S.; Pathania, S.; Banayal, D.K.; Sharma, S.K.; Rathour, R. Molecular mapping of pea powdery mildew resistance gene er 2 to pea linkage group III. Mol. Breed. 2010, 25, 229-237. [CrossRef]

29. Cobos, M.J.; Rubiales, D.; Fondevilla, S. Er3 gene conferring resistance to Erysiphe pisi is located in pea LGIV. In Proceedings of the Second International Legume Society Conference, Troia, Portugal, 11-14 October 2016.

30. Tiwari, K.R.; Penner, G.A.; Warkentin, T.D. Inheritance of powdery mildew resistance in pea. Can. J. Plant. Sci. 1997, 77, 307-310. [CrossRef]

31. Vaid, A.; Tyagi, P.D. Genetics of powdery mildew resistance in pea. Euphytica 1997, 96, 203-206. [CrossRef]

32. Fondevilla, S.; Carver, T.L.W.; Moreno, M.T.; Rubiales, D. Macroscopic and histological characterisation of genes er 1 and er 2 for powdery mildew resistance in pea. Eur. J. Plant. Pathol. 2006, 115, 309-321. [CrossRef]

33. Fondevilla, S.; Cubero, J.I.; Rubiales, D. Confirmation that the Er3 gene, conferring resistance to Erysiphe pisi in pea, is a different gene from er 1 and er2 genes. Plant. Breed. 2011, 130, 281-282. [CrossRef] 
34. Bai, Y.; Pavan, S.; Zheng, Z.; Zappel, N.F.; Reinstadler, A.; Lotti, C.; DeGiovanni, C.; Ricciardi, L.; Lindhout, P.; Visser, R.; et al. Naturally occurring broad-spectrum powdery mildew resistance in a central American tomato accession is caused by loss of MLO1 function. Mol. Plant. Microbe Interact. 2008, 21, 30-39. [CrossRef] [PubMed]

35. Büschges, R.; Hollricher, K.; Panstruga, R.; Simons, G.; Wolter, M.; Frijters, A.; van Daelen, R.; van der Lee, T.; Diergaarde, P.; Groenendijk, J. The barley MLO gene, a novel control element of plant pathogen resistance. Cell 1997, 88, 695-705. [CrossRef]

36. Consonni, C.; Humphry, M.E.; Hartmann, H.A.; Livaja, M.; Durner, J.; Westphal, L.; Vogel, J.; Lipka, V.; Kemmerling, B.; Schulze-Lefert, P.; et al. Conserved requirement for a plant host cell protein in powdery mildew pathogenesis. Nat. Genet. 2006, 38, 716-720. [CrossRef] [PubMed]

37. Devoto, A.; Hartmann, H.A.; Piffanelli, P.; Elliott, C.; Simmons, C.; Taramino, G.; Goh, C.S.; Cohen, F.E.; Emerson, B.C.; Schulze-Lefert, P.; et al. Molecular phylogeny and evolution of the plant-specific seven-transmembrane MLO family. J. Mol. Evol. 2003, 56, 77-88. [CrossRef] [PubMed]

38. Pavan, S.; Schiavulli, A.; Appiano, M.; Marcotrigiano, A.R.; Cillo, F.; Visser, R.G.F.; Bai, Y.; Lotti, C.; Luigi Ricciardi, L. Pea powdery mildew er1 resistance is associated to loss-of-function mutations at a MLO homologous locus. Appl. Genet. 2011, 123, 1425-1431. [CrossRef] [PubMed]

39. Rispail, N.; Rubiales, D. Genome-wide identification and comparison of legume MLO gene family. Sci. Rep. 2016, 6, 32673. [CrossRef]

40. Santo, T.; Rashkova, M.; Alabaca, C.; Leitao, J. The ENU-induced powdery mildew resistant mutant pea (Pisum sativum L.) lines S (er1mut1) and F (er1mut2) harbour early stop codons in the PsMLO1 gene. Mol. Breed. 2013, 32, 723-727. [CrossRef]

41. Fu, H.; Sun, S.; Zhu, Z.; Duan, C.; Yang, X. Phenotypic and genotypic identification of powdery mildew resistance in pea cultivars or lines from Canada. J. Plant. Genet. Resour. 2014, 15, 1028-1033. (In Chinese with English abstract).

42. Ma, Y.; Coyne, C.J.; Main, D.; Pavan, S.; Sun, S.; Zhu, Z.; Zong, X.; Leitão, J.; McGee, R.J. Development and validation of breeder-friendly KASPar markers for er1, a powdery mildew resistance gene in pea (Pisum sativum L.). Mol. Breed. 2017, 37, 151. [CrossRef]

43. Sudheesh, S.; Lombardi, M.; Leonforte, A.; Cogan, N.O.I.; Materne, M.; Forster, J.W.; Kaur, S. Consensus Genetic Map Construction for Field Pea (Pisum sativum L.), Trait dissection of biotic and abiotic stress tolerance and development of a diagnostic marker for the er1 powdery mildew resistance gene. Plant. Mol. Biol. Rep. 2015, 33, 1391-1403. [CrossRef]

44. Pavan, S.; Schiavulli, A.; Appiano, M.; Miacola, C.; Visser, R.G.F.; Bai, Y.L.; Lotti, C.; Ricciardi, L. Identification of a complete set of functional markers for the selection of er 1 powdery mildew resistance in Pisum sativum L. Mol. Breed. 2013, 31, 247-253. [CrossRef]

45. Peng, H.X.; Yao, G. On resistance to powdery mildew of pea varieties Chinese. Acta Phytopathol Sin. 1993, 23, 62. (In Chinese)

46. Liu, A.A. Identification method of resistance of pea to powdery mildew using detached leaves. Acta Phytophylacica Sin. 2002, 29, 19-123. (In Chinese with English abstract).

47. Zeng, L.; Li, M.Q.; Yang, X.M. Identification of resistance of peas resources to powdery mildew. Grassl. Turf. 2012, 32, 35-38. (In Chinese with English abstract).

48. Wang, Z.; Bao, S.; Duan, C.; Zong, X.; Zhu, Z. Screening and molecular identification of resistance to powdery mildew in pea germplasm. Acta Agron. Sin. 2013, 39, 1030-1038. (In Chinese with English abstract). [CrossRef]

49. Lu, J.; Yang, X.; Wang, C.; Yang, F.; Zhang, L. Screening for pea resources resistant to pea powdery mildew in field. Gansu Agr. Sci. Technol. 2015, 41, 154-158, (In Chinese with English abatract).

50. Fu, H. Phenotyping and Genotyping Powdery Mildew Resistance in Pea. Ph.D. Thesis, Gansu Agricultural University, Gansu, China, 2014. (In Chinese with English abstract).

51. Sun, S.; He, Y.; Dai, C.; Duan, C.; Zhu, Z. Two major er1 alleles confer powdery mildew resistance in three pea cultivars bred in Yunnan Province, China. The Crop. J. 2016, 4, 353-359. [CrossRef]

52. Kusch, S.; Panstruga, R. Mlo-based resistance, an apparently universal "Weapon" to defeat powdery mildew disease. MPMI 2017, 30, 179-189. [CrossRef]

53. Kim, E.; Magen, A.; Ast, G. Different levels of alternative splicing among eukaryotes. Nucl. Acids Res. 2007, 35, 125-131. [CrossRef] 
54. Reddy, A.S.N. Alternative splicing of pre-messenger RNAs in plants in the genomic era. Annu. Rev. Plant. Biol. 2007, 58, 267-294. [CrossRef]

55. Ner-Gaon, H.; Halachmi, R.; Savaldi-Goldstein, S.; Rubin, E.; Ophir, R.; Fluhr, R. Intron retention is a major phenomenon in alternative splicing in Arabidopsis. Plant. J. 2004, 39, 877-885. [CrossRef] [PubMed]

56. Barbazuk, W.B.; Fu, Y.; McGinnis, K.M. Genome-wide analyses of alternative splicing in plants, opportunities and challenges. Genome Res. 2008, 18, 1381-1392. [CrossRef] [PubMed]

57. Rubiales, D.; Brown, J.K.M.; Martín, A. Hordeum chilense resistance to powdery mildew and its potential use in cereal breeding. Euphytica 1993, 67, 215-220. [CrossRef]

58. Rana, J.C.; Banyal, D.K.; Sharma, K.D.; Sharma, M.K.; Gupta, S.K.; Yadav, S.K. Screening of pea germplasm for resistance to powdery mildew. Euphytica 2013, 189, 271-282. [CrossRef]

59. Shure, M.; Wessler, S.; Fedoroff, N. Molecular-identification and isolation of the waxy locus in maize. Cell 1983, 35, 225-233. [CrossRef]

60. Bordat, A.; Savois, V.; Nicolas, M.; Salse, J.; Chauveau, A.; Bourgeois, M.; Potier, J.; Houtin, H.; Rond, C.; Murat, F.; et al. Translational genomics in legumes allowed placing in silico 5460 unigenes on the pea functional map and identified candidate genes in Pisum sativum L. Genes Genome Genet. 2011, 1, $93-103$. [CrossRef]

61. Loridon, K.; McPhee, K.; Morin, J.; Dubreuil, P.; Pilet-Nayel, M.L.; Aubert, G.; Rameau, C.; Baranger, A.; Coyne, C.; Lejeune-Hénaut, I.; et al. Microsatellite marker polymorphism and mapping in pea (Pisum sativum L.). Theor. Appl. Genet. 2005, 111, 1022-1031. [CrossRef]

62. Lander, E.S.; Daly, M.J.; Lincoln, S.E. Constructing genetic linkage maps with MAPMAKER/EXP Version 3.0, a tutorial and reference manual. In Institute for Biomedical Research Technical Report, 3rd ed.; Whitehead, A., Ed.; Whitehead Institute for Biomedical Research: Cambridge, MA, USA, 1993.

63. Kosambi, D.D. The estimation of map distances from recombination values. Ann. Eugen. 1944, 12, $172-175$. [CrossRef]

64. Liu, R.H.; Meng, J.L. MapDraw, A Microsoft excel macro for drawing genetic linkage maps based on given genetic linkage data. Hereditas 2003, 25, 317-321. (In Chinese with English abstract).

(C) 2019 by the authors. Licensee MDPI, Basel, Switzerland. This article is an open access article distributed under the terms and conditions of the Creative Commons Attribution (CC BY) license (http://creativecommons.org/licenses/by/4.0/). 